\title{
Groundwater Quality Assessment Based on WQI and Its Vulnerability to Saltwater Intrusion in a Coastal City, Iran
}

\author{
Salman Tavassoli, Farzad Mohammadi* \\ Faculty of Civil Engineering, K. N. Toosi University of Technology, Tehran, Iran \\ Email: *Mohammady.frz@gmail.com
}

How to cite this paper: Tavassoli, S. and Mohammadi, F. (2017) Groundwater Quality Assessment Based on WQI and Its Vulnerability to Saltwater Intrusion in a Coastal City, Iran. Journal of Geoscience and Environment Protection, 5, 88-98. https://doi.org/10.4236/gep.2017.56010

Received: April 21, 2017

Accepted: June 11, 2017

Published: June 14, 2017

Copyright $\odot 2017$ by authors and Scientific Research Publishing Inc. This work is licensed under the Creative Commons Attribution International License (CC BY 4.0).

http://creativecommons.org/licenses/by/4.0/

\begin{abstract}
The purpose of this paper was to assess the quality of groundwater in Behshahr (Iran) based on water quality index (WQI). Sixteen water samples from this coastal aquifer were collected and analyzed to study physico-chemical parameters such as $\mathrm{pH}$, hardness, chloride $(\mathrm{Cl})$, electrical conductivity (EC) and total dissolved solids (TDS). The results showed that the annual average of TDS value increased by $343 \mathrm{mg} / \mathrm{l}$ between 1999 and 2015 due to anthropogenic activities. According to WQI, it was concluded that the groundwater quality degraded over the last sixteen-year period so that the percentage of samples identified as "good water" decreased by $18.5 \%$ and on the other hand, alas, the percentage of "poor water" quality soared by nearly $12.5 \%$. Correspondence of WQI distribution diagram with that of chloride-bicarbonate ratio attests to the significant contribution of saltwater intrusion to groundwater quality deterioration in this area.
\end{abstract}

\section{Keywords}

Groundwater Quality, Water Quality Index, Physico-Chemical Parameters, Saltwater Intrusion, Coastal Aquifers

\section{Introduction}

As demand for freshwater soars and its supplies dwindle, the world water crisis is becoming an enormous challenge. If remaining unsolved, this problem may have catastrophic consequences for humans and wildlife alike. Meanwhile, groundwater which plays a vital role in water supply in innumerable areas has been exploited during last decades. Groundwater pollution, thereupon, has become an acute problem that if thrust aside will escalate to a point of no return. A precise assessment of groundwater quality is required to devise a strategy to 
tackle the issue.

Processes governing groundwater quality are divided into two main categories: anthropogenic and natural factors each of which comprises their own distinctive effects. From anthropogenic perspective, fundamental causes of groundwater pollution are leaked sewage, seawater intrusion, industrial wastewater and fertilizer. Natural causes, on the other hand, encompass geology and geochemical processes, weathering, precipitation, temperature etc [1] [2] [3].

One of the most prevalent threats of groundwater quality deterioration in coastal aquifers is chloride contamination which for the most part occurs due to saltwater intrusion. Pumping from underground resources is the predominant cause of saltwater intrusion in coastal aquifers. It can reduce freshwater flow toward coastal discharge areas and cause saltwater to be drawn toward the freshwater zones of the aquifer. Saltwater intrusion decreases freshwater storage in the aquifers, and, in extreme cases, can result in the abandonment of supply wells [4]. Furthermore, high concentrations of chloride have adverse effects on human health, crops productivity, soil permeability, and durability of equipment used in water distribution systems [5].

It is noteworthy that retrieving the water quality is burdensome and costly once it is polluted especially by saltwater. Regular monitoring of the quality of groundwater, hence, appears to be essential [6].

The importance of groundwater monitoring and the complexity associated with numerous methods reveals the necessity of a simple yet accurate technique for evaluating groundwater quality. Traditional practices mostly include reports with a lot of details about variables and their compliance with official guidelines; however, in many cases, managers and the general public have no tendency to study accurate reports. Summarizing complex water quality data in an exoteric parameter is possible by means of Water quality index (WQI). WQI was first expressed by Horton and later developed in many papers on the water quality monitoring of all around the world [7] [8] [9] [10] [11]. This method has been recognized as a measure that indicates the complex effect of several variables on the overall water quality rating [12].

Since no study has been conducted in this area for groundwater resources, the main objective of this paper is to find the baseline groundwater quality of this region based on WQI and its relevancy to chloride contamination.

\section{Material and Method}

Behshahr is a coastal city in the east of Mazandaran province, Iran. This city is Located on the south coast of the Gorgan gulf (Caspian Sea) at the foot of the Alborz Mountain. The average elevation of the city is about $20 \mathrm{~m}$ above mean sea level also its area is approximately $940 \mathrm{~km}^{2}$ and has a population of 31,875 .

In order to assess groundwater quality, 16 groundwater samples were collected in this study area. For each sample, quality parameters such as $\mathrm{pH}$, TDS, EC, Total hardness, major cations and major anions were measured through the APHA standard methods. The analytical results in 1999 and 2015 are repre- 
sented in Table 1 and Table 2 respectively. The location of sampling wells which are recorded in the Universal Transverse Mercator (UTM) coordinate system is shown in Figure 1 as well.

Being a convenient method to appraise and present water quality for drinking, WQI method was applied to combine and summarize different parameters measured for each sample. This method considers the effect of various water quality parameters on human health. Following four simple steps describe the calculation of WQI [13] [14]:

1) Assigning weight $\left(\mathrm{w}_{\mathrm{i}}\right)$ :

In the first step, weights are assigned to each parameter on a sliding scale of 5 to 1 based on their contribution to water quality from most important, 5 , to the least, 1. Table 3 shows weights relating to each parameter [14].

2) Relative weight $\left(\mathrm{W}_{\mathrm{i}}\right)$ :

Relative weight is calculated using the following Equation:

$$
W_{i}=\frac{W_{i}}{\sum_{i=1}^{n} w_{i}}
$$

where the $\mathrm{w}_{\mathrm{i}}$ is the weight of each parameter and $\mathrm{n}$ is the number of parameters (Table 3).

3) Quality rating scale $\left(q_{i}\right)$ :

Table 1. Physico-chemical parameters for selected water sample in the Behshar basin (1999).

\begin{tabular}{|c|c|c|c|c|c|c|c|c|c|c|c|c|c|c|c|c|}
\hline \multirow{2}{*}{$\begin{array}{c}\text { Sampling } \\
\text { Well }\end{array}$} & \multicolumn{2}{|c|}{$\begin{array}{l}\text { Geographical } \\
\text { Coordinate } \\
\text { (UTM Zone: } 39 \mathrm{~S} \text { ) }\end{array}$} & \multirow{2}{*}{$\mathrm{pH}$} & \multirow{2}{*}{$\begin{array}{c}\text { EC } \\
(\mu \mathrm{S} / \mathrm{cm})\end{array}$} & \multirow{2}{*}{$\begin{array}{l}\text { TDS } \\
(\mathrm{mg} / \mathrm{l})\end{array}$} & \multirow{2}{*}{$\begin{array}{c}\mathrm{TH} \\
(\mathrm{mg} / \mathrm{l} \text { as } \\
\left.\mathrm{CaCO}_{3}\right)\end{array}$} & \multicolumn{4}{|c|}{ Cations (meq/l) } & \multicolumn{4}{|c|}{ Anions (meq/l) } & \multirow{2}{*}{ WQI } & \multirow{2}{*}{ Description } \\
\hline & $\mathrm{X}(\mathrm{m})$ & $\mathrm{Y}(\mathrm{m})$ & & & & & $\mathrm{Ca}$ & K & $\mathrm{Na}$ & $\mathrm{Mg}$ & $\mathrm{HCO}_{3}$ & $\mathrm{CO}_{3}$ & $\mathrm{Cl}$ & $\mathrm{SO}_{4}$ & & \\
\hline W1 & 709300 & 4061450 & 8.9 & 1224 & 796 & 350 & 3.60 & 0.06 & 6.50 & 3.40 & 4.00 & 2.40 & 5.60 & 1.31 & 95.75 & good \\
\hline W2 & 716600 & 4060600 & 8.1 & 584 & 410 & 265 & 2.50 & 0.02 & 1.32 & 2.80 & 4.60 & 0.00 & 1.65 & 0.60 & 56.88 & good \\
\hline W3 & 718100 & 4066050 & 8.3 & 970 & 670 & 230 & 1.00 & 0.05 & 6.14 & 3.60 & 3.40 & 1.80 & 5.00 & 0.45 & 75.5 & good \\
\hline W4 & 718650 & 4062150 & 8.2 & 894 & 583 & 340 & 2.80 & 0.03 & 3.00 & 4.00 & 5.50 & 0.00 & 3.95 & 0.60 & 77 & good \\
\hline W5 & 722760 & 4062800 & 7.8 & 508 & 330 & 285 & 3.90 & 0.01 & 0.29 & 1.80 & 4.90 & 0.00 & 0.45 & 0.74 & 52.66 & good \\
\hline W6 & 724150 & 4065500 & 8 & 1196 & 756 & 405 & 2.30 & 0.03 & 5.72 & 5.80 & 7.30 & 0.00 & 5.50 & 0.82 & 97.52 & good \\
\hline W7 & 725500 & 4067950 & 7.9 & 2054 & 1274 & 743 & 2.90 & 0.09 & 13.38 & 11.9 & 7.10 & 0.00 & 14.30 & 6.20 & 185.63 & poor \\
\hline W8 & 731500 & 4062000 & 8.2 & 588 & 392 & 290 & 3.00 & 0.05 & 0.87 & 2.80 & 4.45 & 0.00 & 0.50 & 1.54 & 58.5 & good \\
\hline W9 & 732400 & 4065100 & 8.3 & 725 & 474 & 360 & 3.20 & 0.02 & 1.12 & 4.00 & 5.55 & 0.60 & 0.50 & 1.48 & 68.32 & good \\
\hline W10 & 736250 & 4066500 & 8.1 & 555 & 375 & 265 & 2.90 & 0.03 & 0.82 & 2.40 & 4.50 & 0.00 & 0.70 & 0.87 & 54 & good \\
\hline W11 & 741900 & 4069400 & 8.1 & 565 & 383 & 320 & 4.10 & 0.01 & 0.47 & 2.30 & 5.50 & 0.00 & 0.50 & 0.42 & 57.71 & good \\
\hline W12 & 742550 & 4063560 & 8.1 & 508 & 314 & 265 & 3.15 & 0.02 & 0.72 & 2.15 & 5.05 & 0.00 & 0.45 & 0.61 & 92.2 & good \\
\hline W13 & 747250 & 4068900 & 8 & 970 & 685 & 470 & 3.60 & 0.04 & 2.16 & 5.80 & 6.80 & 0.00 & 2.15 & 2.27 & 51.42 & good \\
\hline W14 & 750510 & 4071500 & 8.4 & 1017 & 739 & 185 & 1.40 & 0.14 & 7.87 & 2.30 & 4.95 & 1.30 & 3.25 & 2.33 & 82.2 & good \\
\hline W15 & 751650 & 4067600 & 8 & 1224 & 789 & 370 & 4.10 & 0.06 & 6.12 & 3.30 & 5.20 & 0.00 & 6.50 & 2.27 & 100.47 & poor \\
\hline W16 & 752500 & 4071150 & 8.9 & 772 & 508 & 90 & 1.10 & 0.06 & 7.18 & 0.70 & 4.85 & 1.20 & 2.30 & 0.48 & 58.07 & good \\
\hline
\end{tabular}


Table 2. Physico-chemical parameters for selected water sample in the Behshar basin (2015).

\begin{tabular}{|c|c|c|c|c|c|c|c|c|c|c|c|c|c|c|c|c|}
\hline \multirow{2}{*}{$\begin{array}{c}\text { Sampling } \\
\text { Well }\end{array}$} & \multicolumn{2}{|c|}{$\begin{array}{c}\text { Geographical } \\
\text { Coordinate } \\
\text { (UTM Zone: } 39 S \text { ) }\end{array}$} & \multirow[t]{2}{*}{$\mathrm{pH}$} & \multirow{2}{*}{$\begin{array}{c}\mathrm{EC} \\
(\mu \mathrm{S} / \mathrm{cm})\end{array}$} & \multirow{2}{*}{$\begin{array}{l}\text { TDS } \\
(\mathrm{mg} / \mathrm{l})\end{array}$} & \multirow{2}{*}{$\begin{array}{l}\mathrm{TH}(\mathrm{mg} / \mathrm{l} \\
\text { as } \\
\left.\mathrm{CaCO}_{3}\right)\end{array}$} & \multicolumn{4}{|c|}{ Cations (meq/l) } & \multicolumn{4}{|c|}{ Anions (meq/l) } & \multirow[t]{2}{*}{ WQI } & \multirow[t]{2}{*}{ Description } \\
\hline & $\mathrm{X}(\mathrm{m})$ & $\mathrm{Y}(\mathrm{m})$ & & & & & $\mathrm{Ca}$ & $\mathrm{K}$ & $\mathrm{Na}$ & $\mathrm{Mg}$ & $\mathrm{HCO}_{3}$ & $\mathrm{CO}_{3}$ & $\mathrm{Cl}$ & $\mathrm{SO}_{4}$ & & \\
\hline W1 & 709300 & 4061450 & 8 & 1366 & 874 & 355 & 4.40 & 0.08 & 6.10 & 2.70 & 7.20 & 0.00 & 5.70 & 0.60 & 98.82 & Good \\
\hline W3 & 718100 & 4066050 & 7.6 & 1610 & 945 & 335 & 3.10 & 0.09 & 8.90 & 3.60 & 7.80 & 0.00 & 5.10 & 2.80 & 108.83 & Poor \\
\hline W4 & 718650 & 4062150 & 7.9 & 819 & 550 & 325 & 3.40 & 0.05 & 1.70 & 3.10 & 6.50 & 0.00 & 0.90 & 0.80 & 68.80 & Good \\
\hline W5 & 722760 & 4062800 & 7.8 & 514 & 356 & 180 & 2.00 & 0.02 & 1.60 & 1.60 & 4.00 & 0.00 & 0.50 & 0.70 & 45.48 & Excellent \\
\hline W6 & 724150 & 4065500 & 7.7 & 850 & 566 & 330 & 4.50 & 0.05 & 1.90 & 2.10 & 6.10 & 0.00 & 1.40 & 0.90 & 70.73 & Good \\
\hline W7 & 725500 & 4067950 & 7.7 & 7120 & 4557 & 565 & 6.20 & 0.22 & 59.40 & 5.10 & 7.80 & 0.00 & 58.20 & 4.20 & 428.07 & Unsuitable \\
\hline W8 & 731500 & 4062000 & 7.5 & 1210 & 760 & 280 & 2.60 & 0.09 & 5.90 & 3.00 & 5.60 & 0.00 & 4.10 & 1.80 & 86.10 & Good \\
\hline W9 & 732400 & 4065100 & 8 & 1250 & 780 & 450 & 5.50 & 0.08 & 3.10 & 3.50 & 7.70 & 0.00 & 2.20 & 2.10 & 97.04 & Good \\
\hline W10 & 736250 & 4066500 & 7.7 & 950 & 625 & 345 & 4.90 & 0.05 & 2.60 & 2.00 & 6.90 & 0.00 & 1.40 & 1.20 & 76.85 & Good \\
\hline W11 & 741900 & 4069400 & 7.6 & 807 & 541 & 255 & 2.10 & 0.05 & 3.10 & 3.00 & 6.10 & 0.00 & 0.90 & 1.20 & 64.97 & Good \\
\hline W12 & 742550 & 4063560 & 7.9 & 512 & 357 & 180 & 2.10 & 0.07 & 1.50 & 1.50 & 4.00 & 0.00 & 0.50 & 0.60 & 46.20 & Excellent \\
\hline W13 & 747250 & 4068900 & 7.4 & 1192 & 760 & 440 & 5.90 & 0.05 & 2.70 & 2.90 & 8.40 & 0.00 & 1.30 & 1.80 & 92.22 & Good \\
\hline W14 & 750510 & 4071500 & 7.7 & 1450 & 875 & 465 & 6.40 & 0.09 & 4.70 & 2.90 & 7.00 & 0.00 & 3.90 & 3.10 & 108.87 & Poor \\
\hline W15 & 751650 & 4067600 & 7.7 & 1590 & 940 & 290 & 2.90 & 0.08 & 9.50 & 2.90 & 4.70 & 0.00 & 7.60 & 3.00 & 107.06 & Poor \\
\hline W16 & 752500 & 4071150 & 7.8 & 1550 & 930 & 460 & 6.10 & 0.07 & 5.90 & 3.10 & 8.20 & 0.00 & 4.10 & 2.80 & 112.88 & Poor \\
\hline
\end{tabular}

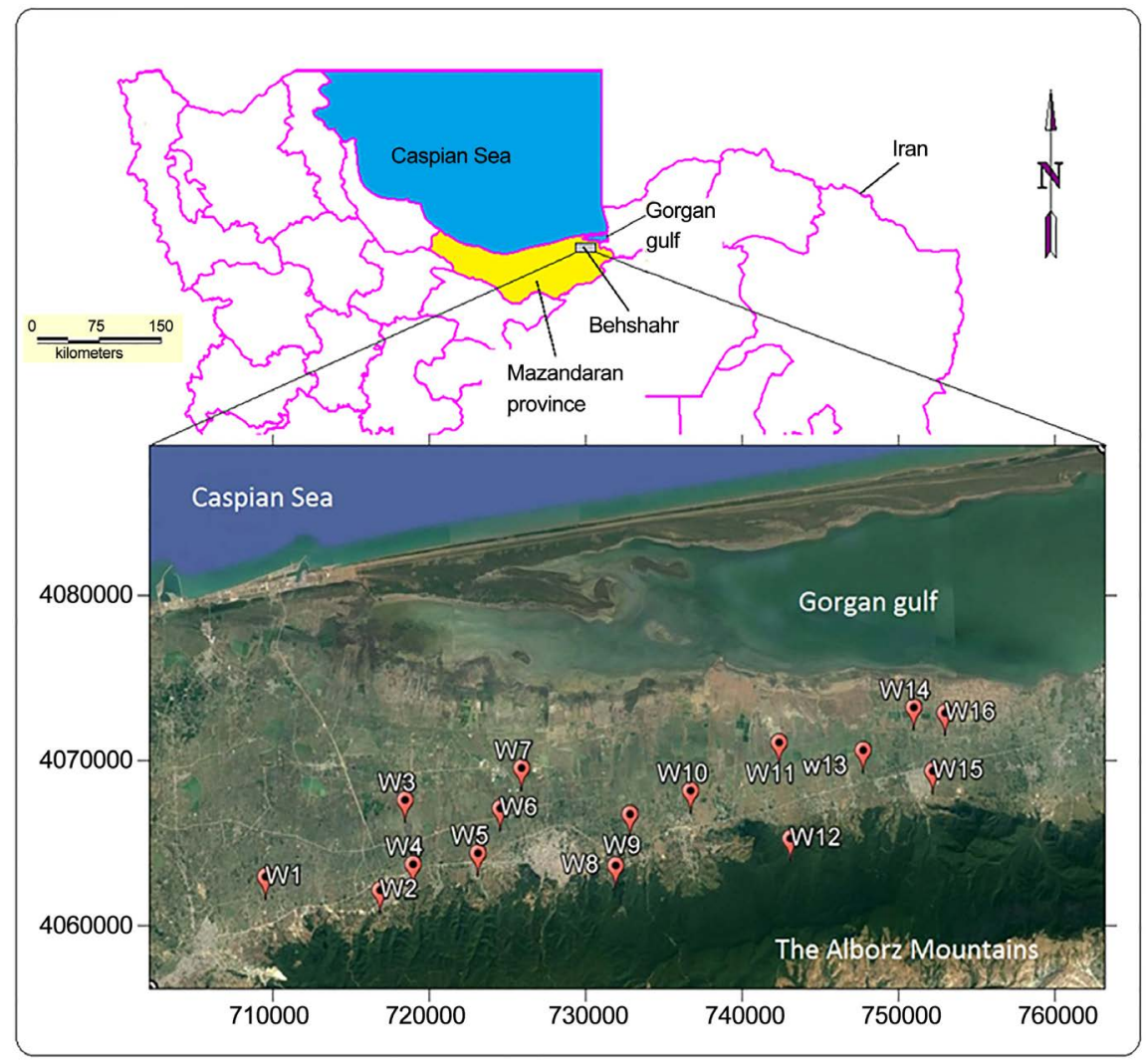

Figure 1. Google image of study area with sampling locations. 
Table 3. Relative weight of physico-chemical parameters and the WHO standard for drinking purpose.

\begin{tabular}{cccc}
\hline Chemical parameters & Weights (wi) & Relative weight $(\mathrm{Wi})$ & $\begin{array}{c}\text { WHO Drinking } \\
\text { Standards }(\mathrm{Si})\end{array}$ \\
\hline $\mathrm{pH}$ & 3 & 0.09 & $6.5-8.5$ \\
$\mathrm{CO}_{3}+\mathrm{HCO}_{3}(\mathrm{mg} / \mathrm{l})$ & 1 & 0.03 & 120 \\
$\mathrm{TDS}(\mathrm{mg} / \mathrm{l})$ & 5 & 0.15 & 500 \\
$\mathrm{Ca}(\mathrm{mg} / \mathrm{l})$ & 3 & 0.09 & 75 \\
$\mathrm{Mg}(\mathrm{mg} / \mathrm{l})$ & 3 & 0.09 & 50 \\
$\mathrm{TH}(\mathrm{mg} / \mathrm{l})$ & 2 & 0.06 & $180^{*}$ \\
$\mathrm{Cl}(\mathrm{mg} / \mathrm{l})$ & 5 & 0.15 & 250 \\
$\mathrm{Na}(\mathrm{mg} / \mathrm{l})$ & 4 & 0.12 & 200 \\
$\mathrm{~K}(\mathrm{mg} / \mathrm{l})$ & 2 & 0.06 & 12 \\
$\mathrm{SO}_{4}(\mathrm{mg} / \mathrm{l})$ & 5 & 0.15 & 250 \\
$\mathrm{Total}$ & 33 & 1.00 & - \\
\hline
\end{tabular}

* USGS allowable limits [16].

The quality rating scale $\mathrm{q}_{\mathrm{i}}$ for each parameter in each sample is determined by dividing the concentration of each parameter by its respective standard $\left(\mathrm{S}_{\mathrm{i}}\right)$ given by WHO multiplied by 100 [15].

$$
q_{i}=\frac{C_{i}}{S_{i}} * 100
$$

where the $C_{i}$ is the concentration of each parameter which is reported in $\mathrm{mg} / \mathrm{l}$ except for $\mathrm{pH}$ which is dimensionless and the $\mathrm{S}_{\mathrm{i}}$ is maximum allowable limit for each parameter in $\mathrm{mg} / \mathrm{l}$ (Table 3 ).

4) Sub-index $\left(\mathrm{SI}_{\mathrm{i}}\right)$ and Water WQI:

To determine the sub-index and the WQI following Equations are applied respectively:

$$
\begin{gathered}
S I_{i}=q_{i} * W_{i} \\
W Q I=\sum_{i=1}^{n} S I_{i}
\end{gathered}
$$

where $\left(\mathrm{SI}_{\mathrm{i}}\right)$ is the sub index of each parameter, $\mathrm{q}_{\mathrm{i}}$ is the quality rating scale of each parameter and $\mathrm{n}$ is the number of parameters.

\section{Result and Discussion}

\subsection{Water Quality}

The water quality analysis of Behshahr showed that $\mathrm{pH}$ values were in the range of 7.4 - 8 in all the sixteen sampling wells. Total hardness, moreover, varied between 180 to $565 \mathrm{mg} / \mathrm{l}$ as $\mathrm{CaCO}_{3}$ indicating a high rate of hardness in the study area.

Variation of TDS and EC were in the range of 356 to $4557 \mathrm{mg} / \mathrm{l}$ and 512 to $7120 \mu \mathrm{S} / \mathrm{cm}$ respectively. As anticipated, by approaching downstream total dis- 
solved solid noticed to be higher in samples. The annual average of TDS has been soared from $592.4 \mathrm{mg} / \mathrm{l}$ to $935.3 \mathrm{mg} / \mathrm{l}$ in a 16-year period of 1999 to 2015 . Currently, this value is disturbingly close to maximum allowable limits of drinking water proposed by WHO (Figure 2). It is mainly caused by anthropogenic activities such as infiltration of agricultural runoff and domestic wastewater or saltwater intrusion. The comparison between the percentage of water quality parameters in the most polluted sample (W7) and of those in seawater, represents significant similarities. These similarities are most noticeable in sodium and chloride concentrations (Figure 3). This could be the result of salt water intrusion into this aquifer which is highly probable since the area is located in the vicinity of Caspian Sea.

The chloride-bicarbonate ratio is a well-known and decent index to identify saltwater intrusion in coastal areas [17]. According to Raghunath, the ratio of $\mathrm{Cl} / \mathrm{HCO}_{3}=2.8$ is assumed to be the threshold of saltwater intrusion. The distribution of the mentioned ratio in this study area between 1999 and 2015 indicates that not only W7 is already contaminated by saltwater intrusion but also the threshold of saltwater intrusion has significantly moved landward during these years (Figure 4).

Effective and immediate policies, consequently, entailing prevention of overexploitation of threatened wells along with injecting fresh water into these wells are highly recommended.

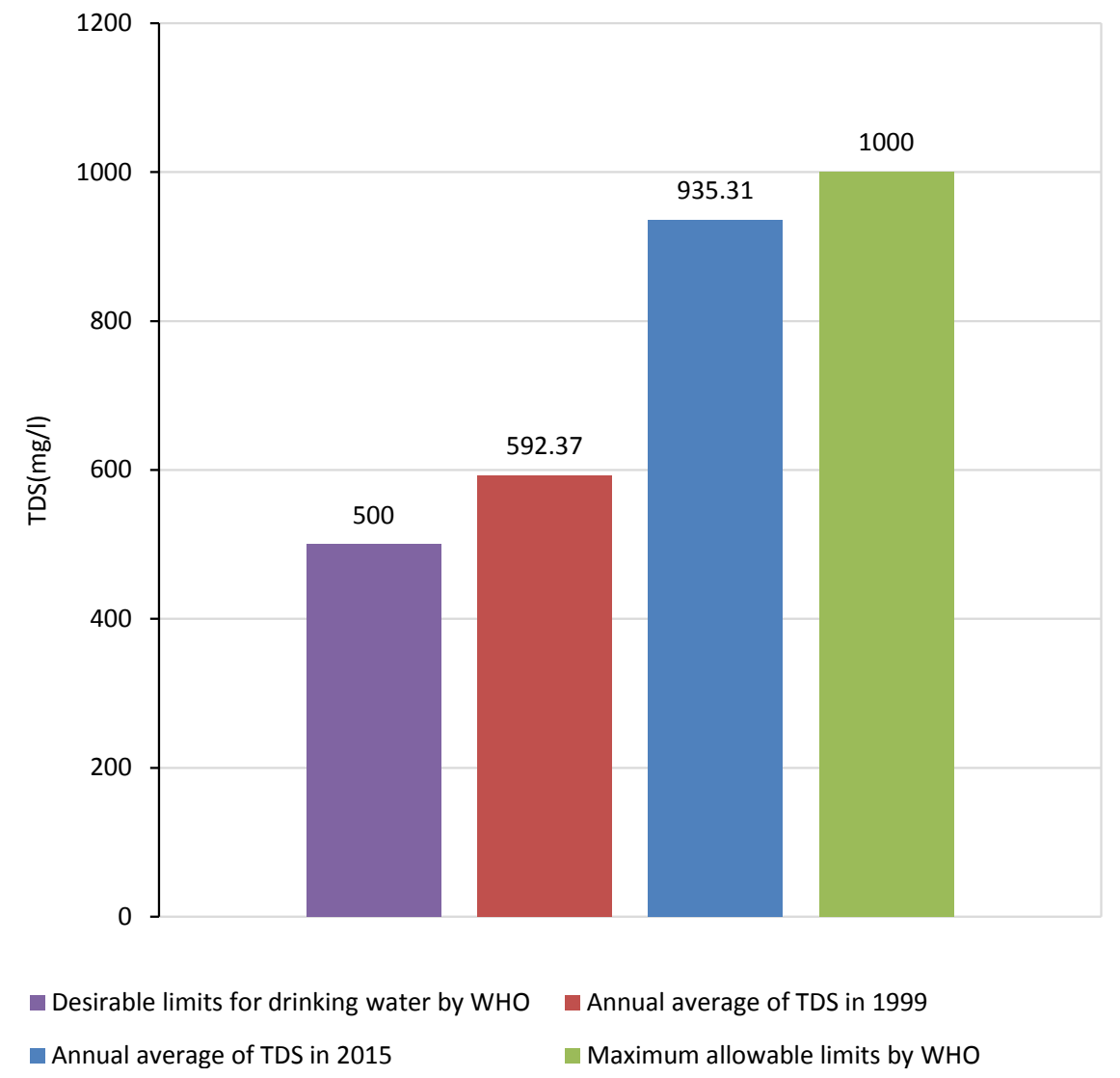

Figure 2. Annual average growth of TDS between 1999 and 2015. 


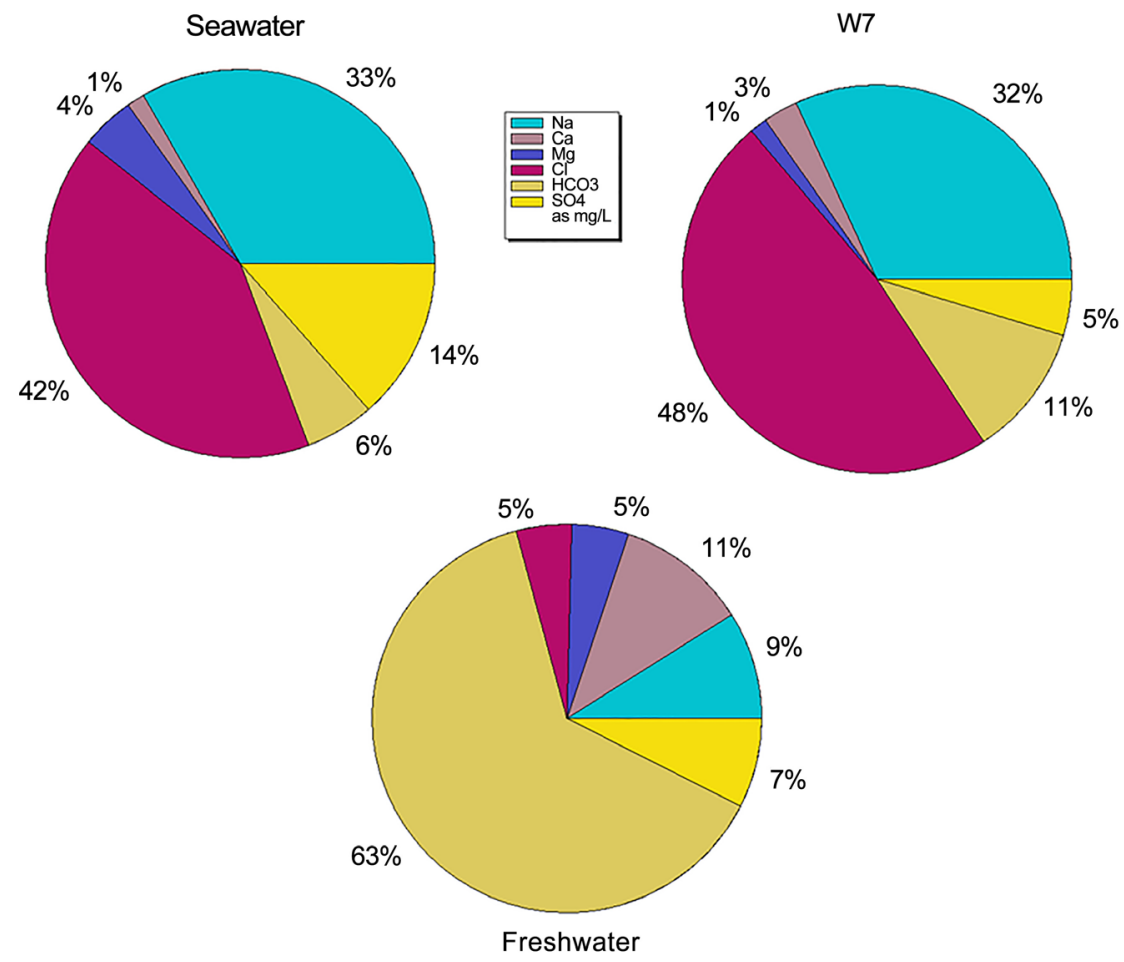

Figure 3. Comparison between percentages of water quality parameters in seawater with that of W7.

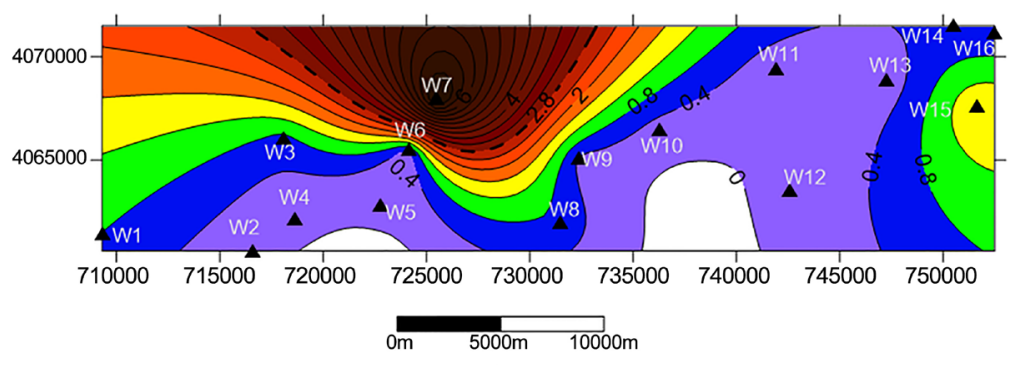

(b)

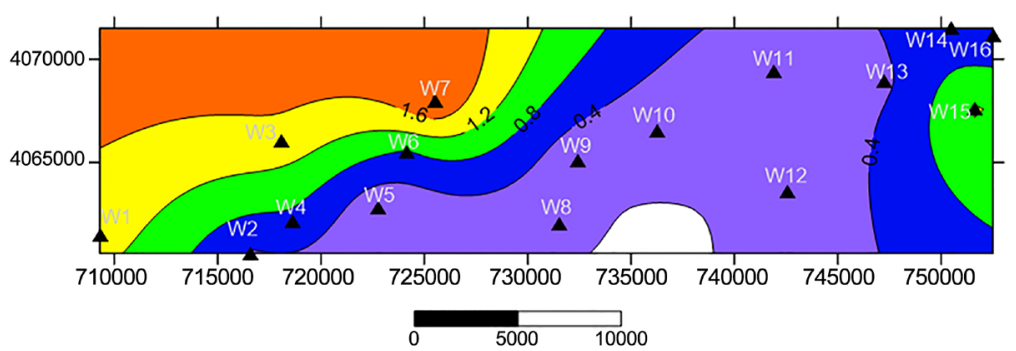

(a)

Figure 4. Distribution of Chloride-bicarbonate ratio between 1999(a) and 2015(b).

\subsection{Water Quality Index}

Calculation WQI can entail as many qualitative parameters as researchers desire. However, its outcome is a single dimensionless figure which represents water quality in each sample [12]. 
In this study eleven parameters including $\mathrm{pH}, \mathrm{TDS}, \mathrm{TH}$, major cations and anions were considered to partake in WQI calculation. Taking into account the significance of each parameter on human health, weights were allocated to them. Results categorized samples into four different groups based on guidelines proposed by WHO and U.S. Geological Survey. Variation of WQI parameter was in the range of 45.48 to 428.07 in 2015 (Table 4). In order to achieve a general understanding of water quality in the area, distribution of WQI is shown in Figure 5.

According to Table 4 and Figure 5, it is found that in 2015 about $56.25 \%$ of the groundwater samples which covered a wide-range of this study area fitted into good category while in 1999 about $87.5 \%$ of samples fitted into this category. Since the water quality of those samples identified as "good water" is approximately close to natural condition, they are suitable for direct human consumption.

Table 4. Water quality index (WQI) legend.

\begin{tabular}{cccc}
\hline WQI Range & $\begin{array}{c}\text { Percentage of samples } \\
(2015)\end{array}$ & $\begin{array}{c}\text { Percentage of } \\
\text { samples (1999) }\end{array}$ & Quality \\
\hline $50<$ & 12.5 & 0 & Excellent \\
$50-100$ & 56.25 & 87.5 & Good \\
$100-200$ & 25 & 12.5 & Poor \\
$200-300$ & 0 & 0 & Very poor \\
$>300$ & 6.25 & 0 & Unsuitable for drinking \\
\hline
\end{tabular}

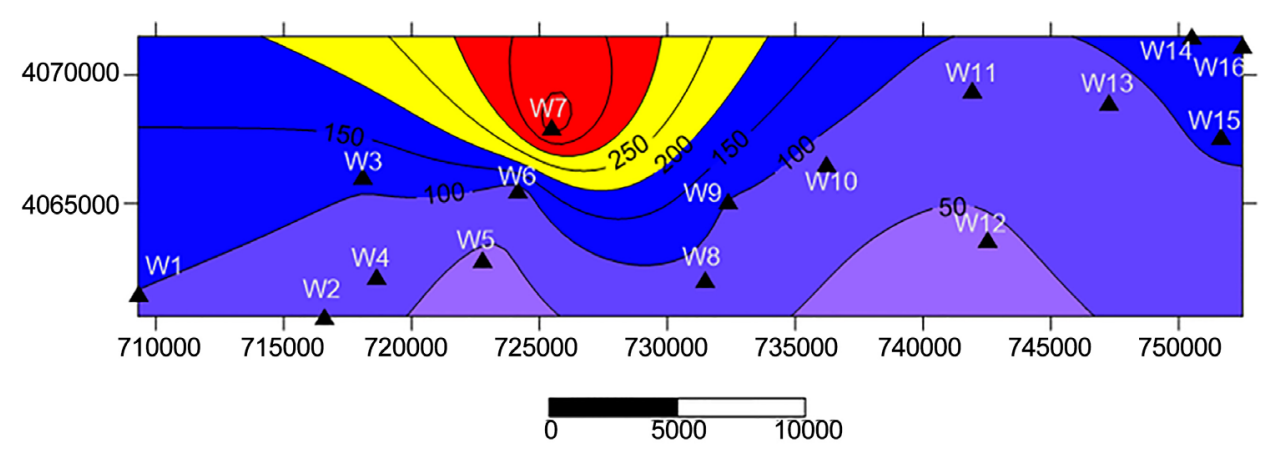

(b)
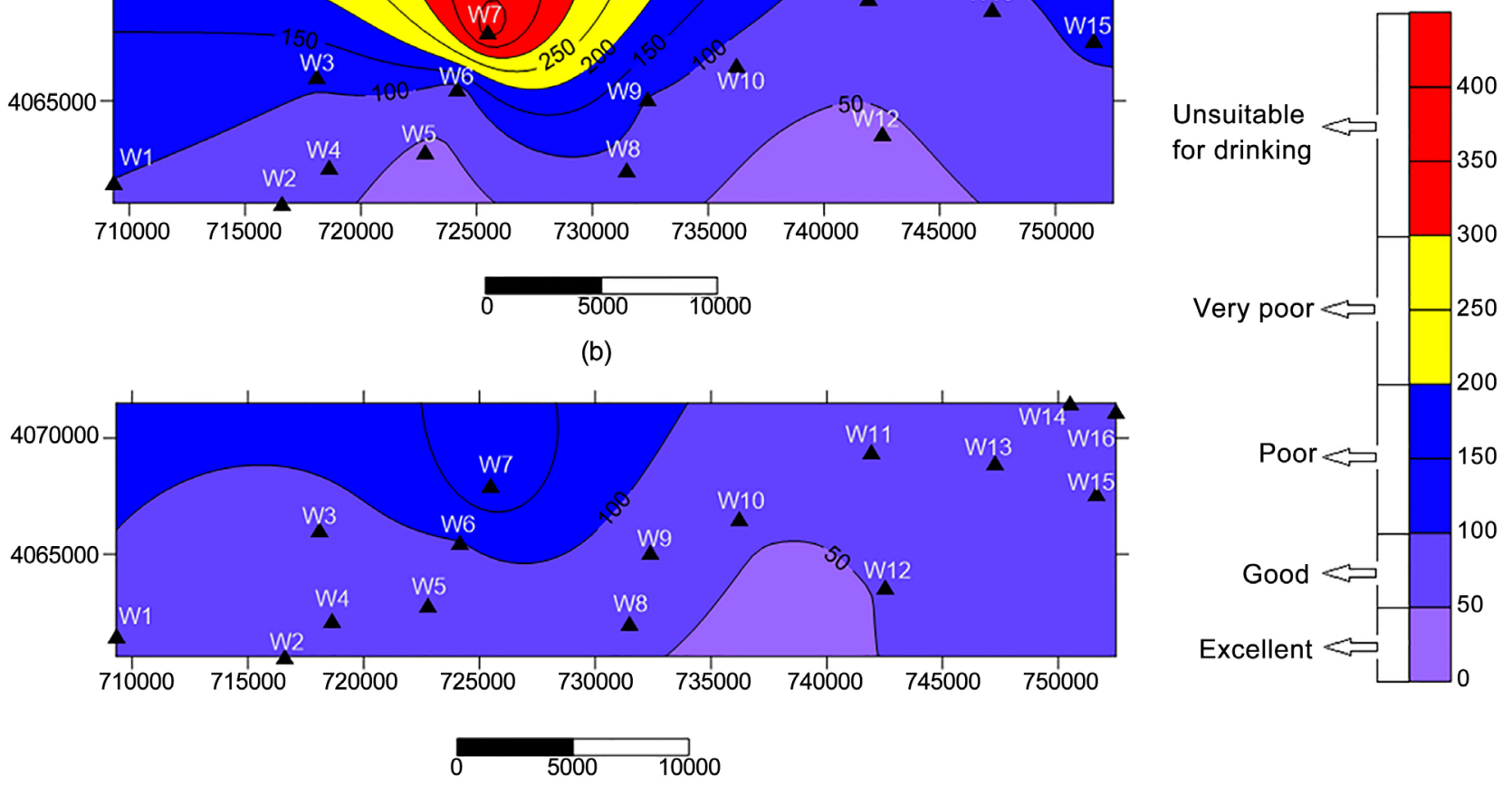

(a)

Figure 5. WQI distribution of sampling wells between 1999(a) and 2015(b). 


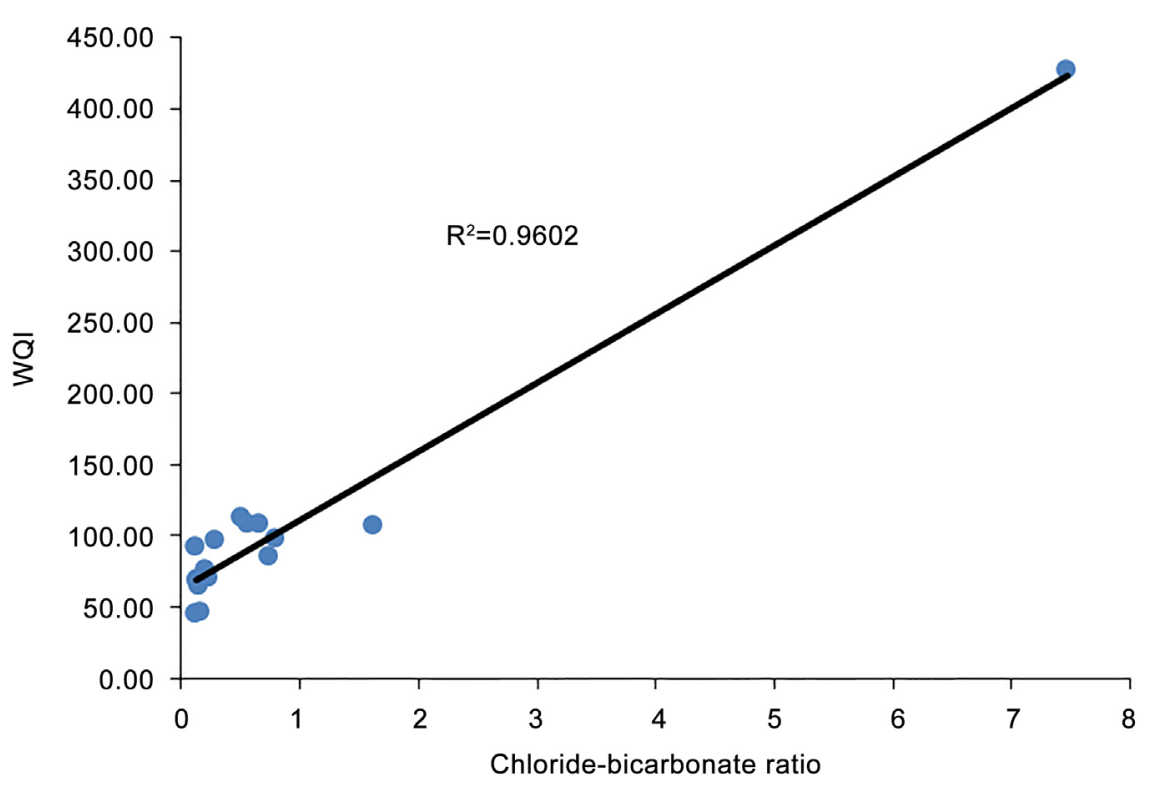

Figure 6. Correlation coefficient between WQI and chloride-bicarbonate ratio.

Regarding the excellent category, although an increase of $12.5 \%$ can be observed between 1999 and 2015, the improvements in the water quality occurring in W5 was fairly insignificant and probably reflect natural events, furthermore, the improvement in W12 might have occurred as a result of being located in the recharge area which could make it quite sensitive to the raw water quality.

As can be seen in Table 4 in 2015 nearly 25\% of samples fitted into poor category. Comparing to $12.5 \%$ of those in this category in 1999, it showed a twofold increase. The quality of water in these samples mostly located in northern and western part of this basin are occasionally threatened or impaired. Consequently, they can be only used for irrigation, bathing and swimming, though for drinking, industrial or laundry purposes conventional treatment is highly recommended.

Since the water quality of those samples fitted into poor category occasionally depart from natural state, it is suggested that the mentioned category be considered as the threshold of unnatural activities. This consideration helps policy makers to make optimized decisions based on priority and importance of each quality zones to prevent groundwater contamination.

Through approaching northern parts of the basin, water quality perceived to be impaired. This is especially pronounced in W7 which fitted into "Unsuitable for drinking" category in 2015 whereas in 1999 it was located in the zone that was just in progress to be impaired. Water quality in W7 has been drastically affected by high concentration of TDS and sodium chloride during this period of time.

The parallelism between distribution diagrams of WQI and chloride-bicarbonate reveals the fact that threshold of saltwater intrusion fairly corresponds with the very poor quality zone. Assigning a high weight to chloride in WQI calculation is a contributing factor to this similarity. This makes the results 
highly sensitive to drastic changes in chloride concentration. In addition, the correlation coefficient between chloride-bicarbonate ratio and WQI confirms that saltwater intrusion plays leading role in water quality deterioration in this study area (Figure 6).

\section{Conclusions}

In this study area annual average of TDS increased nearly $343 \mathrm{mg} / \mathrm{l}$ and reached to $935 \mathrm{mg} / \mathrm{l}$ in 2015 due to anthropogenic activity. The WQI rating represented various water quality categories in this study area. In 1999 about $87.5 \%$ of groundwater samples were suitable for drinking purpose whereas in 2015 the number of potable samples decreases to $69 \%$ of all groundwater samples. In a related vein, number of samples belonging to poor category increased about $12.5 \%$ over this period of time. This means extracted water from these wells and that in the immediate vicinity is only to be used for irrigation, bathing or swimming unless conventional treatment is conducted.

The comparison between Percentage of seawater quality parameters and those of in W7 represented significant similarities especially in sodium-chloride concentration. Furthermore, comparing the chloride-bicarbonate distribution diagram in the last 16-year period indicated that saltwater/freshwater interface has significantly moved landward.

The correspondence between WQI distribution and chloride-bicarbonate ratio shows that the main reason of very poor water quality zone is chloride contamination and also the correlation coefficient between aforementioned parameters confirms that saltwater intrusion is the most possible consequence of anthropogenic activities in this coastal area.

Accordingly, to gain a true understanding of water quality in an area WQI is highly recommended. This simple yet precise method presents a comprehensive interpretation of water quality in a basin. Its sensitivity to chloride that has high weight makes it a good measure for seeking out the threshold of saltwater intrusion in this study area. Relying on this method's results a basin can be divided into different zones with different water usages. Policy makers would achieve a great benefit utilizing this method.

\section{References}

[1] Shim, B.Y., Chung, S.Y., Kim, H.J., Sung, I.H. and Kim, B.W. (2002) Characteristics of Sea Water Intrusion Using Geostatistical Analysis of Geophysical Surveys at the Southeastern Coastal Area of Busan, Korea. Journal of Soil and Groundwater Environment, 7, 3-17.

[2] Chung, S.Y., Kim, T.H. and Park, N. (2012) The Influence of the Surrounding Groundwater by Groundwater Discharge from the Subway Tunnel at Suyeong District, Busan City. Journal of Soil and Groundwater Environment, 17, 28-36. https://doi.org/10.7857/JSGE.2012.17.2.028

[3] Tayfur, G., Kirer, T. and Baba, Alper, (2008) Groundwater Quality and Hydrogeochemical Properties of Torbali Region, Izmir, Turkey. Environmental Monitoring and Assessment, 146, 157-169. https://doi.org/10.1007/s10661-007-0068-6 
[4] U.S. Geological Survey. January 3, 2017.

https://water.usgs.gov/ogw/gwrp/saltwater/salt.html

[5] Pius, A., Jerome, C. and Sharma, N. (2012) Evaluation of Groundwater Quality in and around Peenya Industrial Area of Bangalore, South India Using GIS Techniques. Environmental Monitoring and Assessment, 184, 4046-4077. https://doi.org/10.1007/s10661-011-2244-y

[6] Vasanthavigar, M., Srinivasamoorthy, K., Vijayaragavan, K., Rajiv Ganthi R., Chidambaram, S., Anandhan, P., Manivannan, R. and Vasudevan, S. (2010) Application of Water Quality Index for Groundwater Quality Assessment: Thirumanimuttar Sub-Basin, Tamilnadu, India. Environmental Monitoring Assessment, 17, 595609. https://doi.org/10.1007/s10661-009-1302-1

[7] Horton, R.K. (1965) An Index Number System for Rating Water Quality. Journal of the Water Pollution Control Federation, 37, 300-306.

http://www.scirp.org/(S(i43dyn45teexjx455qlt3d2q))/reference/ReferencesPapers.as px?ReferenceID $=1020268$

[8] Pradhan, S.K., Patnaik, D. and Rout, SP. (2001) Groundwater Quality Index for Groundwater around a Phosphatic Fertilizers Plant. Indian Journal of Environmental Protection, 21, 355-358.

[9] Ramakrishnaiah, C.R., Sadashivaiah. C. and Ranganna, G. (2009) Assessment of Water Quality Index for the Groundwater in Tumkur Taluk, Karnataka State, India. E-Journal of Chemistry, 6, 523-530. https://doi.org/10.1155/2009/757424

[10] Pei-Yue, L., Hui, Q. and Jian-Hua, W. (2010) Groundwater Quality Assessment Based on Improved Water Quality Index in Pengyang Plain, Ningxia, Northwest China. E-Journal of Chemistry, 7, 209-216. https://doi.org/10.1155/2010/451304

[11] Amiri, V., Rezaei, M. and Sohrabi N. (2014) Groundwater Quality Assessment Using Entropy Weighted Water Quality Index (EWQI) in Lenjanat, Iran. Environmental Earth Sciences, 72, 3479-3490. https://doi.org/10.1007/s12665-014-3255-0

[12] Khadse, G.K., Patni, P.M. and Labhasetwar, P.K. (2016) Water Quality Assessment of Chenab River and Its Tributaries in Jammu Kashmir (India) Based on WQI. Sustainable Water Resources Management, 2, 121-126. https://doi.org/10.1007/s40899-016-0046-7

[13] Xiao, J., Jin, Z. and Wang, J. (2013) Assessment of the Hydrogeochemistry and Groundwater Quality of the Tarim River Basin in an Extreme Arid Region, NW China. Environmental Management, 53, 135-146. https://doi.org/10.1007/s00267-013-0198-2

[14] Aly, A.A., Al-Omran, A.M. and Alharby, M.M. (2014) The Water Quality Index and Hydrochemical Characterization of Groundwater Resources in Hafar Albatin, Saudi Arabia. Arabian Journal of Geosciences, 6, 4177-4190.

[15] World Health Organization (WHO) (1993) Guidelines for Drinking Water Quality, Recommendations. Geneva, $130 \mathrm{p}$.

[16] U.S. Geological Survey. 28 October 2014. https://water.usgs.gov/owq/hardness-alkalinity.html\#hardness

[17] Raghunath, H.M. (1990) Groundwater. Wiley Eastern Limited, 563 p. 
Submit or recommend next manuscript to SCIRP and we will provide best service for you:

Accepting pre-submission inquiries through Email, Facebook, LinkedIn, Twitter, etc. A wide selection of journals (inclusive of 9 subjects, more than 200 journals)

Providing 24-hour high-quality service

User-friendly online submission system

Fair and swift peer-review system

Efficient typesetting and proofreading procedure

Display of the result of downloads and visits, as well as the number of cited articles Maximum dissemination of your research work

Submit your manuscript at: http://papersubmission.scirp.org/

Or contact gep@scirp.org 